\title{
Isolation of a Mutant Secreting Extracellular Soluble Alkaline Phosphatase in Bacillus subtilis
}

\author{
Kunio Yamane, Takeyoshi Miki,* Hiuga SaIto, \\ Yonosuke IKEDA and Bunji MARUo \\ Institute of Applied Microbiology, The University of Tokyo, \\ Bunkyo-ku, Tokyo, Japan \\ Received May 24, 1976
}

\begin{abstract}
A mutant (RAN 1) which produced extracellular soluble alkaline phosphatase was isolated from $B$. subtilis $6160-\mathrm{BC} 6$ that constitutively produced phosphate-repressible alkaline phosphatase. The mutant produced the enzyme after the cell growth reached maximum and most of the enzyme produced was secreted into the culture medium at every culture period tested. The distribution of the enzyme in culture fluids and in cells of the mutant was quite similar to that of $\alpha$-amylase while alkaline phosphatase in B. subtilis $6160-\mathrm{BC} 6$ was particulate and located mainly in cell membrane.
\end{abstract}

Bacillus subtilis produces many kinds of extracellular enzymes. This bacterium also produces phosphate-repressible alkaline phosphatase $^{1,2)}$ as in a variety of microorganisms including Escherichia coli, ${ }^{3,4)}$ Pseudomonas fluorescens, $\left.{ }^{5}\right)$ Aerobactor aerogenes ${ }^{6)}$ and Neurospora crassa. ${ }^{7}$ The alkaline phosphatase in B. subtilis has been shown to be tightly associated with cytoplasmic membrane in biochemical and histochemical investigations. ${ }^{8,9)}$ The enzyme was extracted by highly concentrated solutions $(1 \mathrm{M})$ of magnesium salt. $2,8,10,11\rangle$

To elucidate the recognition mechanism of determing different locations of extracellular enzymes and membrane bound enzymes, we isolated a mutant of $B$. subtilis which produced extracellular soluble alkaline phosphatase as in the case of extracellular $\alpha$-amylase.

\section{MATERIALS AND METHODS}

Strains used and isolation of mutants. A mutation for constitutive production of phosphate-repressible alkaline phosphatase in mutant B. subtilis BC6 (arg, $\operatorname{trp} B 3$, alkaline phosphatase constitutive) $)^{13}$ was transferred into $B$. subtilis $6160(\operatorname{trp} B 3$, metB5, purB6), a derivative of $B$. subtilis Marburg 168, through congression transformation with high concentration of

* Present address: Department of Pharmacology, Kyushu University, Fukuoka, Japan.
DNA. A transformant $B$, subtilis $6160-B C 6(\operatorname{trp} B 3$, metB5, alkaline phosphatase constitutive) was isolated. Then the strain was subjected to treatment with 100 $\mu \mathrm{g} / \mathrm{ml}$ of $\mathrm{N}$-methyl-N-nitro- $\mathrm{N}^{\prime}$-nitrosoguanidine for $15 \mathrm{~min}$ at $37^{\circ} \mathrm{C}$ in Tris (hydroxymethyl) aminomethane (Tris)-malate buffer at $\mathrm{pH} 6.0$. The treated cells were washed, suspended in $20 \%$ glycerol and stored in liquid nitrogen until use. A sample of the cells was melted quickly, grown for $4 \mathrm{hr}$ at $37^{\circ} \mathrm{C}$ in $\mathrm{BY}$ medium, ${ }^{12)}$ and then spread on BY-medium agar plates. After colonies appeared on the plates, they were covered with sterile nitrocellulose filters (Sartorius membrane filter, $0.20 \mu)^{13)}$ The filters, the face of which was adhered most of the colonies upwards, were fitted on HPmedium agar plates and held overnight at room temperature. Filters with cells were removed, and filterpapers (Toyo Roshi Filterpaper, No. 2) soaked with p-nitrophenyl phosphate $(2 \mathrm{mg} / \mathrm{ml}$ of $0.2 \mathrm{M}$ Tris- $\mathrm{HCl}$ buffer of $\mathrm{pH} 9.0$ ) were pressed on the surface of the plates. Alkaline phosphatase activity diffusing through the agar plates was detected as yellow spots of $p$ nitrophenol liberated. Colonies on the nitrocellulose filters corresponding to the yellow spots were picked up as mutants.

Media. HP- and LP-medium contained $2.2 \mathrm{~mm}$ and $0.22 \mathrm{mM} \mathrm{PO}_{4}^{-}$in the basal medium, ${ }^{12}$ respectively.

Alkaline phosphatase activity. Alkaline phosphatase activity in liquid cultures was assayed by the modified method of Schlesinger. ${ }^{14)} p$-Nitrophenyl phosphate $(0.2 \mathrm{mg} / \mathrm{ml}$ of $0.1 \mathrm{M}$ Tris- $\mathrm{HCl}$ buffer of $\mathrm{pH}$ 9.0) was used as the substrate. One unit of enzyme activity is shown by the increase in absorbance at $420 \mathrm{~nm}$ at $40^{\circ} \mathrm{C}$ per minute $\times 1000$. 
Amylase activity. Amylase activity was assayed by the modified method of Fuwa. ${ }^{15)}$

Chemicals. Nitrocellulose filters were purchased from Sartorius-Membrane Filter GMBH, 34 Göttingen, West Germany. Filterpaper were from Toyo Roshi Kaisha, Ltd., Tokyo. N-Methyl-N-nitro-N'-nitrosoguanidine was from Daiichi Pure Chemical Co., Tokyo. $p$-Nitrophenyl phosphate was from Wako Pure Chemical Industries, Osaka. All other chemicals were of reagent grade.

\section{RESULTS}

From about 90,000 tested colonies, 16 colonies (RAN $1 \sim 16$ ) were selected as mutants. They produced alkaline phosphatase which passed through the nitrocellulose filter into agar of HP-medium agar plates. The enzyme in the parent $B$. subtilis $6160-\mathrm{BC} 6$ could not pass through the filter. Among the 16 mutants selected, three mutants (RAN 1 3) showed normal spore formation but the others (RAN 4 16) were spore-less mutants.

Possible changes in the distribution and pro- duction of alkaline phosphatase of the isolated mutants were investigated in HP- and LP. medium and compared with those of $B$. subtilis 6160 and $6160-B C 6$. Representatives of the 16 mutants were summarized in Table I. From 20 to $40 \%$ of alkaline phosphatase produced in B. subtilis 6160 and $6160-$ BC6 were located in the culture fluids but almost all enzyme activity was precipitated by ultracentrifugation at $60,000 \times g$ for $60 \mathrm{~min}$. In a mutant RAN 1 , the production of alkaline phosphatase was reduced in both media with more than $80 \%$ of the enzyme being secreted into the culture fluids. Furthermore almost all enzyme activity was recovered in the supernatant of the ultracentrifugation. The same enzyme distribution in the culture medium of the mutant was observed in BY-medium (data not shown).

On the other hand, $70 \sim 80 \%$ of the enzyme in other mutants (RAN $2 \sim 16$ ) were found in the extracellular fraction of HP-medium. However, almost all activity was precipitated by ultracentrifugation as shown in the enzyme

Table I. Production and Distribution of Alkaline Phosphatase in B. subtilis 6160, B. subtilis 6160-BC6 AND In REPRESENTATIVE ISOLATED MUTANTS

Cells were cultured at $30^{\circ} \mathrm{C}$ for $24 \mathrm{hr}$ in each medium.

The culture medium was separated into extracellular fraction and cells by centrifugation at $1000 \times g$ for $20 \mathrm{~min}$.

\begin{tabular}{|c|c|c|c|c|c|c|c|c|}
\hline \multirow[b]{2}{*}{ Strains } & \multicolumn{4}{|c|}{ HP-medium } & \multicolumn{4}{|c|}{ LP-medium } \\
\hline & $\begin{array}{l}\left.\text { Cells }{ }^{a}\right) \\
(\mathrm{U} / \mathrm{ml})\end{array}$ & $\begin{array}{l}\text { Extracel- } \\
\text { lular }^{b)} \\
(\mathrm{U} / \mathrm{ml})\end{array}$ & $\begin{array}{c}\begin{array}{c}\text { Extracel- } \\
\text { lular }^{\circ)}\end{array} \\
\text { Total } \\
(\%)\end{array}$ & $\begin{array}{c}\text { Supernatant } t^{d)} \\
\text { Extracellular } \\
(\%)\end{array}$ & $\begin{array}{l}\text { Cells } \\
(\mathrm{U} / \mathrm{m})\end{array}$ & $\begin{array}{l}\text { Extracel- } \\
\text { lular }^{b)} \\
(\mathrm{U} / \mathrm{ml})\end{array}$ & $\begin{array}{c}\begin{array}{c}\text { Extracel- } \\
\text { lular }\end{array} \\
\begin{array}{c}\text { Total } \\
(\%)\end{array}\end{array}$ & 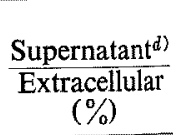 \\
\hline B. subtilis & & & & & & & & I \\
\hline 6160 & 6 & 2 & - & - & 185 & 130 & 41.3 & 4.8 \\
\hline $6160-B C 6$ & 670 & 444 & 39.6 & 2.7 & 544 & 336 & 38.2 & 1.8 \\
\hline \multicolumn{9}{|l|}{ Mutant } \\
\hline RAN 1 & 16 & 220 & 93.2 & 92,3 & 36 & 195 & 84.8 & 92.7 \\
\hline RAN 2 & 129 & 524 & 80.2 & 5.5 & 305 & 335 & 52.3 & 2.7 \\
\hline RAN 5 & 78 & 383 & 83.1 & 6.9 & 657 & 172 & 20.7 & 10.1 \\
\hline RAN 9 & 110 & 367 & 76.9 & 9.2 & 481 & 155 & 24.4 & 24.2 \\
\hline RAN 14 & 193 & 454 & 70.2 & 8.7 & 430 & 192 & 30.9 & 16.8 \\
\hline RAN 16 & 26 & 104 & 80.0 & 15.1 & 433 & 89 & 17.1 & 20.0 \\
\hline
\end{tabular}

a) Cells were washed and suspended in the original volume of $0.01 \mathrm{M}$ Tris-HCl buffer of $\mathrm{pH} 7.5$ containing $2 \mathrm{~mm}$ calcium acetate and $1 \mathrm{~mm}$ cobalt chloride. Alkaline phosphatase activity in the cells was assayed after the cells were treated with toluene.

b) Alkaline phosphatase activity in the extracellular fraction.

c) Percentage of alkaline phosphatase secreted into the medium.

d) Percentage of soluble alkaline phosphatase in the medium. The extracellular fraction was further ultracentrifuged at $60,000 \times g$ for $60 \mathrm{~min}$. Alkaline phosphatase activity in the supernatant was measured and then calculated. 


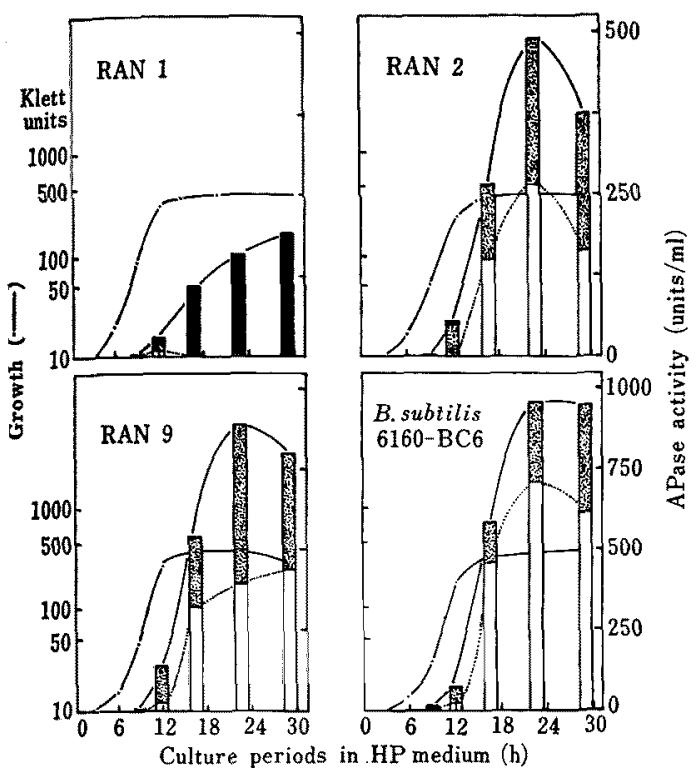

Fig. 1. Time Courses of the Production and Distribution of Alkaline Phosphatase and the Growth of Mutant 1, 2, and 9 and the Parent B. subtilis 6160BC6.

In each culture period indicated, the culture medium was separated into extracellular fraction (눈) and cells $(\square)$ as shwon in the footnote of Table I. The extracellular fraction was further separated into the supernatant ( $\boldsymbol{D}$ ) and pellet by ultracentrifugation at $60,000 \times g$ for $60 \mathrm{~min}$. The pellet was suspended in the original volume of $0.01 \mathrm{M}$ Tris $\mathrm{HCl}$ buffer of pH 7.5 containing $2 \mathrm{~mm}$ calcium acetate and $1 \mathrm{~mm}$ cobalt chloride and then assayed ( of the parents in spite of the difference in filterability through the nitrocellulose filter. In LP-medium no essential differences in the distribution of enzyme were observed between the parents and mutants (RAN $2 \sim 16$ ).

The amounts of $\alpha$-amylase, protease and ribonuclease produced by mutants in LP-, $\mathrm{HP}$ - and BY-medium were not significantly changed from the amounts of the enzymes of B. subtilis 6160 and $6160-\mathrm{BC} 6$.

Time courses on the production and distribution of alkaline phosphatase in mutants RAN 1, 2 and 9 and in B. subtilis 6160-BC6 in HP-medium are shown in Fig. 1. Growth of the three mutants and $6160-\mathrm{BC} 6$ equally reached maximum at about $12 \mathrm{hr}$ after inoculation, and then the production of alkaline phosphatase was began. Most of the enzyme produced by RAN 1 was secreted into the ultracentrifugal supernatant at every culture period tested. RAN 2 and 9 showed similar patterns of enzyme production to the parent B. subtilis $6160-\mathrm{BC} 6$. They produced a particulate form of the enzyme in the extracellular fraction and cells. The distribution ratios of the enzyme in the two fraction were higher in mutants than in the parent as shown in Table I. A small amount of alkaline phosphatase

Table II. Localization of Alkaline Phosphatase and Amylase Activity in B. subtilis 6160-BC6 AND MUTANT RAN 1

\begin{tabular}{|c|c|c|c|c|c|c|c|c|}
\hline \multirow[b]{2}{*}{ Fractions } & \multicolumn{4}{|c|}{ B. subtilis $6160-\mathrm{BC} 6$} & \multicolumn{4}{|c|}{ RAN 1} \\
\hline & $\begin{array}{c}\text { APase } \\
(\mathrm{U} / \mathrm{ml})\end{array}$ & $\begin{array}{r}\text { activity } \\
(\%)\end{array}$ & $\begin{array}{l}\text { Amylase } \\
(\mathrm{U} / \mathrm{ml})\end{array}$ & $\begin{array}{c}\text { activity } \\
(\%)\end{array}$ & $\begin{array}{c}\text { APase } \\
(\mathbf{U} / \mathrm{ml})\end{array}$ & $\begin{array}{l}\text { tivity } \\
(\%)\end{array}$ & $\begin{array}{l}\text { Amyla } \\
(\mathrm{U} / \mathrm{ml})\end{array}$ & $\begin{array}{c}\text { activity } \\
(\%)\end{array}$ \\
\hline Culture medium ${ }^{a)}$ & 1,732 & 100.0 & 5.69 & 100.0 & 609 & 100.0 & 6.00 & 100.0 \\
\hline Extracellular fraction ${ }^{b 3}$ & 372 & 18.9 & 5.38 & 94.6 & 567 & 93.1 & 5.63 & 93.8 \\
\hline Supernatant ${ }^{b)}$ & 28 & 1.6 & 5.47 & 96.1 & 519 & 85.2 & 5.41 & 90.2 \\
\hline Pellet $^{(b)}$ & 316 & 18.2 & 0.39 & 6.9 & 21 & 3.4 & 0.21 & 3.5 \\
\hline Washed cells $\left.{ }^{b}\right)$ & 1,415 & 81.7 & 0.31 & 5.4 & 45 & 7.4 & 0.37 & 6.2 \\
\hline Lysozyme supernatant ${ }^{c}$ ) & 78 & 4.5 & 0.23 & 4.0 & 23 & 3.8 & 0.35 & 5.8 \\
\hline Protoplast lysate $\left.{ }^{d}\right)$ & 1,465 & 84.6 & 0.21 & 3.7 & 23 & 3.8 & 0.21 & 3.5 \\
\hline Cytoplasmic supernatant ${ }^{e)}$ & 40 & 2.3 & 0.16 & 2.8 & 8 & 1.3 & 0.16 & 2.7 \\
\hline Cytoplasmic membrane $f$ ) & 1,490 & 86.0 & 0.21 & 3.7 & 23 & 3.8 & 0.10 & 1.7 \\
\hline
\end{tabular}

a) Total enzyme activity in the whole culture medium including cells.

b) See the footnote of Table I and Fig. 1.

c) Supernatant $(6000 \times \mathrm{g}, 30 \mathrm{~min})$ of protoplast formed solution containing lysozyme digested wall components.

d) Lysate of protoplast in $0.01 \mathrm{M}$ Tris- $\mathrm{HCl}$ buffer of $\mathrm{pH} 7.5$ containing $2 \mathrm{~mm}$ calcium acetate and $1 \mathrm{mM}$ cobalt chloride.

e) Supernatant $(60,000 \times g, 60 \mathrm{~min})$ of the protoplast lysate.

f) Pellet $(60,000 \times g, 60 \mathrm{~min})$ of the protoplast lysate. 
was observed in the ultracentrifugal supernatant at every culture period.

Since RAN 1 produced alkaline phosphatase as an extracellular soluble enzyme, the distribution of the enzyme in the mutant and the parent 6160-BC6 was compared with the distribution of $\alpha$-amylase in the two strains (Table II). Alkaline phosphatase in the parent 6160BC6 was located mainly within cells and almost all of it was specifically recovered in cytoplasmic membrane fraction. On the other had, $\alpha$-amylase in the strain was mainly located in the ultracentrifugal supernatant of the extracellular fraction. A considerable amount of $\alpha$-amylase was also located within the cells but the activity was not localized in any specific fraction as with alkaline phosphatase. $\alpha$ Amylase was recovered in all four fractions of cells.

The location of alkaline phosphatase in RAN 1 was quite similar to that of $\alpha$-amylase. The enzyme activity was located mainly in the ultracentrifugal supernatant and the enzyme found in the cells was recovered in the four fractions as in the case of $\alpha$-amylase.

\section{DISCUSSION}

We have isolated a mutant from a derivative of B. subtilis Marburg 168 which produces extracellular soluble alkaline phosphatase as extracellular $\alpha$-amylase.

Alkaline phosphatases in $B$. subtilis, ${ }^{2,8,9,11)}$ $B$. megaterium ${ }^{8}$ and $B$. licheniformis ${ }^{10}$ were tighly bound to cell membrane and could not be solubilized by osmotic shock ${ }^{16)}$ or by protoplast formation with lysozyme in the presence of sucrose. ${ }^{17)}$ These methods were used for liberation of alkaline phosphatase in $E$. coli in which the enzyme is known to be localized in the periplasmic space of the cells. ${ }^{17}$ ) It was reported that alkaline phosphatases purified from derivatives of $B$. subtilis Marburg strain were insoluble in isotonic solutions. ${ }^{2,11)}$

The parental strain $B$. subtilis $6160-\mathrm{BC} 6$, a transformant containing a mutation for constitutive production of alkaline phosphatase seemed to produce insoluble alkaline pho- sphatase. From 20 to $40 \%$ of total alkaline phosphatase activity was apparently secreted into the culture media by the strain but it was almost completely precipitated by ultracentrifugation. In contrast, alkaline phosphatase produced by the mutant RAN 1 was soluble in the solutions. It was not precipitated by ultaracentrifugation as $\alpha$-amylase did not. It may be quite important in secretion of alkaline phosphatase in RAN 1 whether the enzyme is soluble in isotonic solution or not. Solubility of the enzyme is closely related to enzyme structure itself but the mutation site(s) in chromosome for enzyme secretion in RAN 1 did not locate in its structural gene (K. Yamane et al., unpublished). Enzyme solubility could be one of the important factors in the secretion of extracellular enzymes but the difference in solubility alone would not suffice to explain the different distributions of extracellular enzymes and membrane bound enzymes.

It is reported that in periplasmic leaky mutants of E. coli and S. typhimurium, alkaline phosphatase, ribonuclease I and endonuclease I were secreted into the culture fluid in the absence of leakage of intracellular enzymes. ${ }^{8)}$

Other mutants (RAN 2 16) produced particulate alkaline phosphatases as the parent. Further experiments are necessary to explain why alkaline phosphatases of these mutants were able to pass through the nitrocellulose filters.

Acknowledgment. We thank Mr. S. Shinomiya for his helpful discussion.

\section{REFERENCES}

1) T. Miki, Z. Minami and Y. Ikeda, Genetics, 52, 1093 (1965).

2) K. Takeda and A. Tsugita, J. Biochem. (Tokyo), 61, 231 (1967).

3) T. Horiuchi, S. Horiuchi and D. Mizuno, Nature, 183, 1529 (1959).

4) A. Torriani, Biochim. Biophys. Acta, 38, 460 (1960).

5) I. Friedberg and G. Avigad, Eur. J. Biochem., 1, 193 (1967).

6) R. Wolfenden and G. Spence, Biochim. Biophys. Acta, 146, 296 (1967).

7) R. J. Kadner, J. F. Nyc and D. M. Brown, J. 
Biol. Chem., 2433076 (1968).

8) D. A. W. Wood and H. Tristram, J. Bacteriol., 104, 1045 (1970).

9) B. K. Ghosh, J. T. M. Wouters and J. O. Lampen, ibid., 108, 928 (1971).

10) F. M. Hulett-Cowling and L. L. Campbell, Biochemistry, 10, 1364 (1971).

11) J. -C. L. Hégarat and C. Anagnostopoulos, Eur. J. Biochem., 39, 525 (1973).

12) K. Kadowaki, J. Hosoda and B. Maruo, Biochim. Biophys. Acra, 103, 311 (1965).
13) J. A. Wechsler, V. Nusslein, B. Otto, A Klein, F. Bonhoeffer, R. Herrmann, L. Gloger, and H. Schaller, J. Bacteriol., 113, 1381 (1973).

14) M. J. Schlesinger, J. Biol. Chem., 242, 1604 (1967).

15) H. Fuwa, J. Biochem. (Tokyo), 41, 583 (1954).

16) L. A. Heppel, Science, 156, 1451 (1967).

17) M. Malamy and B. L. Horecker, Biochem. Biophys. Res. Commun., 5, 104 (1961).

18) J. Lopes, S. Gottfried and L. Rothfield, $J$. Bacteriol., 109, 520 (1972). 